University of Nebraska - Lincoln

DigitalCommons@University of Nebraska - Lincoln

Agronomy \& Horticulture -- Faculty Publications

Agronomy and Horticulture Department

6-1953

\title{
Quantitative Study of Degeneration of Mixed Prairie
}

Farrell Branson

J. E. Weaver

University of Nebraska-Lincoln

Follow this and additional works at: https://digitalcommons.unl.edu/agronomyfacpub

Part of the Plant Sciences Commons

Branson, Farrell and Weaver, J. E., "Quantitative Study of Degeneration of Mixed Prairie" (1953). Agronomy \& Horticulture -- Faculty Publications. 444.

https://digitalcommons.unl.edu/agronomyfacpub/444

This Article is brought to you for free and open access by the Agronomy and Horticulture Department at DigitalCommons@University of Nebraska - Lincoln. It has been accepted for inclusion in Agronomy \& Horticulture -Faculty Publications by an authorized administrator of DigitalCommons@University of Nebraska - Lincoln. 


\title{
QUANTITATIVE STUDY OF DEGENERATION OF MIXED PRAIRIE
}

\author{
CONTRIBUTION NO. 160 FROM THE DEPARTMENT OF BOTANY, \\ UNIVERSITY OF NEBRASKA
}

FARREL BRANSON AND J. E. WEAVER

\section{Introduction}

The vegetation of great areas of Mixed Prairie has been destroyed by plowing. But even larger ones, still intact, have degenerated far from a climax condition. The almost universal cause for such deterioration, aside from drought, is grazing. The objective of this study has been to ascertain the changes in vegetation that have resulted from 60-70 years of different intensities of grazing by cattle and to express them quantitatively. Since the early work of SAMPSON (7) it has been generally recognized that the forage value and carrying capacity are highest where the vegetation represents a stage close to the herbaceous climax and that they are lowest in the type most remote from the climax.

Studies on degeneration of various grasslands are necessary, since responses of vegetation to different intensities of grazing vary with the soil, climate, and climax vegetation. The physiographic region selected for this study is known as the Loess Hills and Plains of central Nebraska. It lies southeast of the great Sandhill Region of west-central Nebraska. A total of 2255 square miles, about $48 \%$, of the upland loess soils of the four major counties in the region (Buffalo, Custer, Valley, and Sherman) is covered with the native prairie sod (8).
Physiography, solls, and Climate

The general physiography is that of an upland plain, ranging from almost level to steeply rolling or hilly land. Stream erosion and wind action have produced considerable relief. Over the greater part of the area the upland plain has been dissected and is now hilly. The hills are often 100-150 feet higher than the valleys between them. Nearly all the region is well drained by rivers and streams flowing southeastward into the Platte River, and runoff is extensive and erosion severe over large areas.

The parent-material of the soils of the region is loess. The most extensive soil series are Holdrege and Colby. Throughout the well-drained, gently undulating or rolling areas, conditions have favored the development of mature soils of the Holdrege series. But over much of the area Colby soils occupy the greater portion of the uplands.

The A horizon of the Holdrege soil is dark in color and varies from 10 to 20 inches in depth. The B horizon is characterized by its heavier texture-caused by the accumulation of fine particles leached from the A horizon - and by its grayishbrown color. The lower part of the $B$ horizon has a concentration of salts, chiefly carbonates, carried down in solution from overlying layers. This horizon varies in thickness from 14 to 48 inches. 
The C horizon consists of deep, mellow, highly calcareous loess.

Colby soils occupy the most severely eroded parts of loessial uplands, and rapid surface runoff has prevented the accumulation of much organic matter. The A horizon is grayish-brown and extends to an average depth of 6 inches; it is slightly darker than the lower layers.
The grayish-brown $B$ horizon ranges in thickness from 20 to 30 inches and contains a zone of carbonate accumulation in its lower portion. The parent-material, or C horizon, lies at a depth of 2.5-4 feet and consists of light-gray, floury silt.

These mellow loess soils, originally described by HAYEs et al. (5), are very receptive to water, especially under a

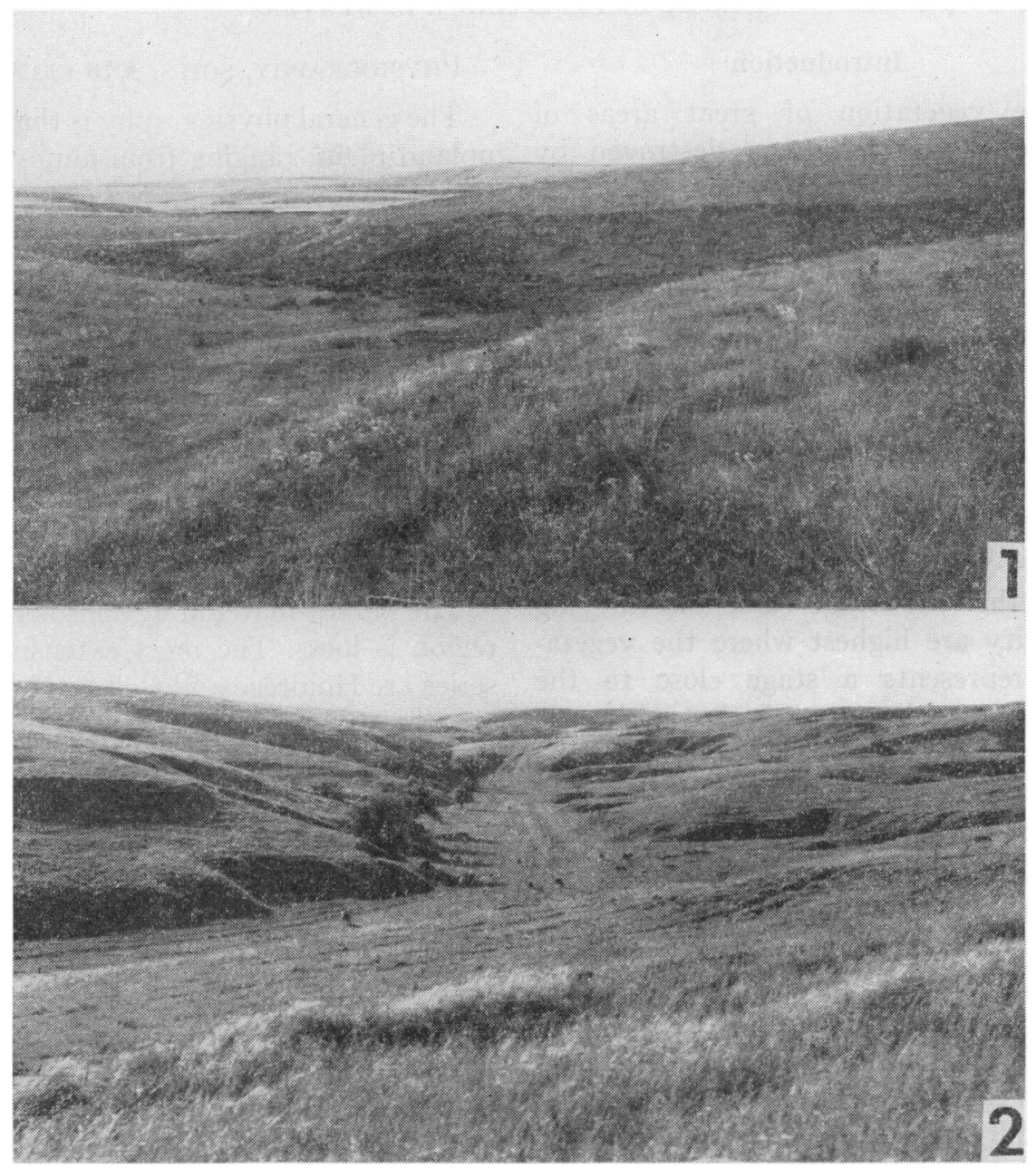

Figs. 1, 2.-Fig. 1, general view of loess-hill topography, near Ansley, Nebraska. Ravines and lower slopes were originally occupied by Andropogon gerardi and other tall and mid grasses, but hilltops were clothed with short grasses, especially Bouteloua gracilis. Mid slopes were covered mostly with mid and short grasses. Fig. 2, view in old pasture 10 miles northeast of Broken Bow, Nebraska. The extensive ravine, lower slopes, and terraces are sites of mid and tall grasses. Mid slopes are also prominent, and hilltop sites occur along horizon. 
cover of grass. Hence the water penetrates deeply, and vegetation is correspondingly deeply rooted. Because of the steeply rolling to hilly topography where Colby soils occur, they have largely remained in native sod.

The climate is typical of the central Great Plains region. The mean annual precipitation is approximately 23.5 inches. The relative humidity is usually low, and the rate of evaporation high. The growing season includes an average of 148 days without severe frost. Winters are moderately cold, and summers are hot.

\section{Climax vegetation}

A very definite concept of the nature of the climax vegetation is essential in tracing the degeneration of grassland. The steep loess hills, with their rounded or flat tops, extensive slopes, and intervening valleys and terraces, provide environments favorable to very different plant communities. Each of these communities presented a separate problem in its history of degeneration. To trace the changes that had occurred, constant reference to natural conditions in these grasslands was made, since ungrazed prairies adjoined, or were in close proximity to, the areas intensively studied.

The native grassland communities were delimited and described by WEAVER and Bruner (10). Their detailed structure and environmental relationships have been ascertained by Hopkins (6). Every considerable sample--actually, almost every square mile- of this Mixed Prairie included three communities or types of vegetation. These were short grass on the hilltops and drier upper slopes, a postclimax of mid and tall grasses in the ravines and on the moist lower slopes, and mixed short and taller grasses in areas on hillsides where an environment intermediate to the two preceding prevailed (figs. 1, 2). A fourth community of western wheatgrass (Agropyron smithii) ${ }^{1}$ resulted from drought. Some western wheatgrass was found in all the preceding climax communities where drought-bared soil had occurred.

Of the short-grass type WEAVER and Bruner (10) stated: "The most important characteristic of this community was the fact that the short grasses, blue grama (Bouteloua gracilis) and buffalo grass (Buchloe dactyloides), dominated usually in almost pure stands or even where there was an intermixture of taller grasses, such as side-oats grama (Bouteloua curtipendula). A second characteristic of great importance was the fact that blue grama was far more abundant than buffalo grass. The latter was often entirely lacking or, if present, it nearly always occurred as a species of less importance in virgin, ungrazed prairie." Hopkins (6) stated: "Typically the short-grass faciation occurred on the hilltops and extended some distance down the hillsides. . . . This faciation never occurred in the ravines, on catsteps, or on steep banks" (fig. 3).

The distribution of the mid- and tallgrass type was described by WeAver and BRUNER (10): "On the lower slopes of the hills and in the ravines, which mostly have broad flat bottoms, there are environments favorable to the development of mid- and tall-grass vegetation. Many ravines have banks with slopes which reach a vertical distance of 10 to 25 feet above the level bottom. These are partially protected from wind and sun and in addition they receive much runoff water from the surrounding

\footnotetext{
${ }^{1}$ Nomenclature of grasses follows Hutchcock's Manual of the Grasses of the United States; that of other species is according to BRITTON and Brow's Illuslrated Flora unless other authority is given.
} 
upland. . . . Where the soil had slumped to produce catsteps on the hillsides, vegetation was of much the same type as in the valleys and ravines. . . B Big bluestem (Andropogon gerardi) was the chief dominant in all such places as it was also in streaks and patches on moist, protected hillsides." Side-oats grama also occurred widely in this community, characteristic layered vegetation of Mixed Prairie." They also stated: "Western wheatgrass was found in greater or lesser amounts in every prairie examined.... In amount it varied from almost complete replacement or overtopping of the other vegetation ... to patches so small or stands so thin that they had little effect upon the prairie

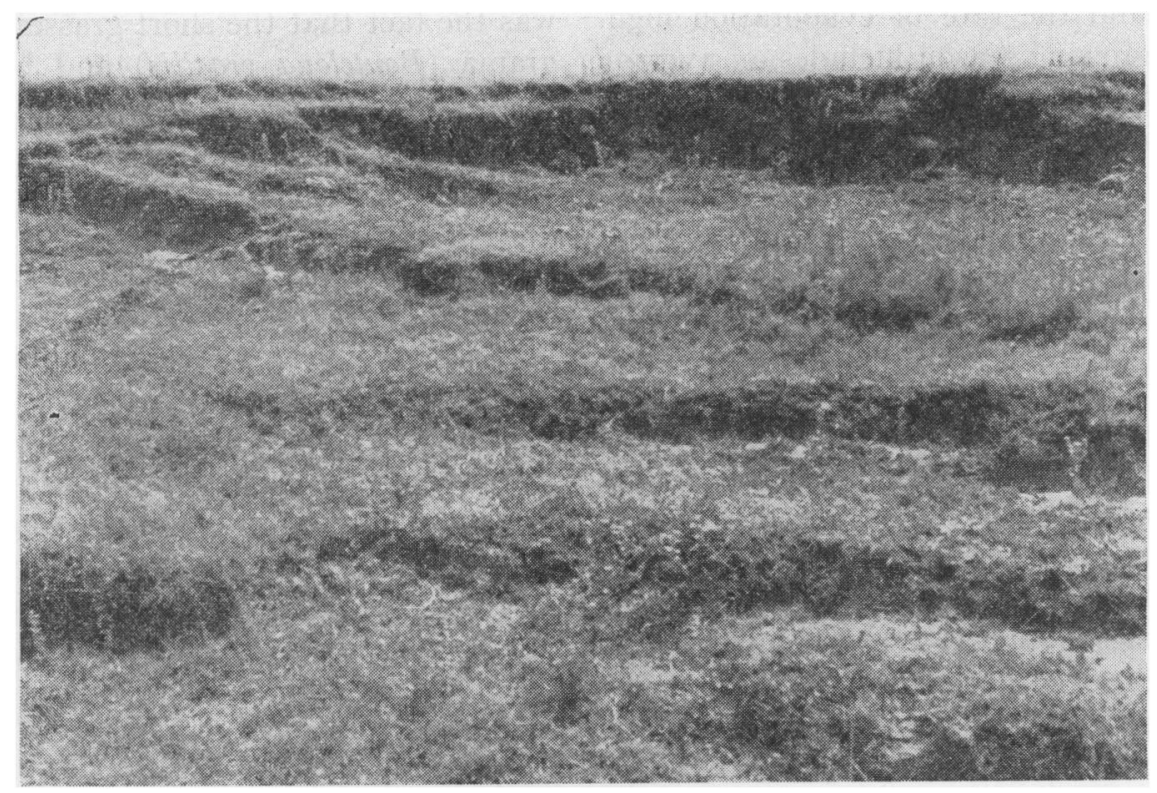

FIG. 3.-Catsteps on side of valley near Kearney, Nebraska, resulting from slipping and settling of soil. They vary from 1 to 15 feet or more in width and have a higher-than-normal water supply. Here both mid and tall grasses are common.

intermingling with the short grasses over great areas.

Regarding the mixed-grass community of taller grasses, as side-oats grama, big bluestem, and western wheatgrass, with an understory of short grasses, WEAVER and BRUNER (10) stated: "In addition to the short-grass type and the much more mesic one composed of tall and mid grasses, there were transitional areas of considerable extent [on hillsides] where species from the two types grew more or less in equal abundance, forming the cover as a whole." This type need not be given further consideration here, since western wheatgrass occurred very sparingly, if at all, in pastured areas selected for this study.

Of the three communities of grassland, HopkrNs (6) ascertained that the short-grass type occupied approximately a third of the area. The mixed-grass type had about the same extent, and $25 \%$ was clothed with the mid and tall grasses of the post-climax community. The relative mesophytism of the three 
communities is in the preceding sequence, the short-grass habitat being the driest. Here effective precipitation was usually decreased by runoff water which aided in moistening the lower slopes and lowlands. In the short-grass type Hopkins (6) ascertained that in summer, wind movement was much greater here, and temperatures and evaporation were much higher than elsewhere. Conversely, humidity was lower.

\section{Stages of DEgENERATION}

Degeneration of excellent ranges with climax vegetation to poor ones populated largely with weeds is a continuous process. When the climax condition and the extremes of degeneration are known, intermediate stages can be distinguished. The classification used in this study includes four grades of pastures or rangecondition classes: excellent, good, fair, and poor $(3,4,9,11,12)$.

Each of the range-condition classes may be identified by the composition of the vegetation. This may be done by using the chief species alone but is somewhat more easily accomplished by using a group classification based upon the responses of plants to grazing. Such a classification of plants of True Prairie was presented by WEAVER and HANSEN (11) in 1941. They classified plants into six groups: (1) prairie grasses and (2) prairie forbs that decrease under grazing, (3) prairie grasses and (4) forbs that increase under grazing, and (5) grasses and (6) forbs that invade overgrazed pastures. This classification has been applied widely in grasslands of North America. The percentages of plants in climax Mixed Prairie that decrease, increase, or invade differ somewhat from those in True Prairie, although many of the species are the same. Short grasses, for example, which are important increasers in True Prairie, make up only a small percentage of the climax vegetation, but in Mixed Prairie they are major components of the climax.

Variations in topography of a region result in different environments, often termed "sites," that are capable of supporting different plant communities. The rough topography of the dissected loess plains presented three distinct siteshilltops, hillsides, and lowlands. The hilltop sites represented the general distribution of the short-grass type in undisturbed prairie, while the hillside habitat extended from the upper to the lower limits of the mixed-grass type. The lowland site included the level bottoms of ravines and ravine banks and wellwatered terraces. It had a cover of mid and tall grasses in native prairie. Thus vegetation was used as the indicator of site; its distribution usually very clearly revealed the environmental conditions. Arbitrary separation of hilltops from hillsides and these from lowlands was thereby avoided.

Since the coming of the cattlemen in 1869-70, this vast tract of Mixed Prairie has been used chiefly for grazing. The cattle ranges of the region, especially the larger ones in the western part, were usually grazed only in summer. In winter, cattle were fed the hay harvested from native meadows. Another practice often employed was to protect one unit of the range during the entire summer and use it for winter grazing. On some of the smaller farm units, however, the range areas were very limited, and there were no prairies from which hay could be mowed. These ranges were often heavily grazed during the entire year, except when covered with snow, and they were usually in only fair or poor condition. 


\section{Methods}

Preliminary surveys were made during the summer of 1948. A part of the survey included mapping the types of vegetation of entire ranges. This was done to obtain information regarding the distribution of the plant communities. Detailed studies were made in widely separated ranges by means of basalarea and pantograph-chart quadrats. The vegetation of individual pastures was frequently compared with that of adjacent prairie.

Four pastures, each representative of a range-condition class, were selected in 1949 near Ansley for intensive study. These will be designated as "experimental pastures." These large pastures (80-160 acres) were similar topographically, and all were on soils mapped by the U.S. Bureau of Chemistry and Soils as Colby silt loam. Data from studies in these pastures were supplemented by results obtained from other pastures throughout the general loess-hills area.

The square-foot quadrat was used in determining percentage composition of vegetation, frequency of occurrence of various species of grasses, and basal area. The manner in which the quadrat was used was the same as that of VoIGT and Weaver (9). Samples were located at regular distances along predetermined lines. The presence of all species, other than annuals, was recorded. The basal area occupied by the vegetation 1 inch above the soil surface was estimated in each fourth of the quadrat, and the average of the four numbers was recorded. In ascertaining percentage composition of the vegetation, the total vegetation, regardless of its amount, was considered as unity or $100 \%$. Usually two or three grasses formed the bulk of the vegetation, the total of their separate percentages of composition amounting to 80-90. The percentage of each species was based upon the part of the total basal area (now considered as 100\%) that each furnished.

Samples were taken at intervals of twenty-five to fifty paces. They were always taken several rods from any fence, although the fences were used as an approximate guide in laying out an area similar in shape but perhaps only two-thirds as large as that of the pasture. It was along the boundaries of this smaller area that the regularly spaced samples were studied. Disturbed areas, such as occur in the immediate vicinity of ponds or wells, were not sampled, since in all pastures these areas had degenerated to weeds or were bare of vegetation as a result of trampling. More than a thousand samples were taken in thirtyseven pastures selected for study.

Distribution of forbs was ascertained by means of circles 50 square feet in area. They were marked out, and the number of individual species of perennial forbs was obtained at predetermined intervals along the lines where the samples of grasses were examined. A total of 256 of these larger areas were studied in thirty pastures representing excellent to poor range-condition classes. Forbs were classified in these ranges as "decreasers," "increasers," or "invaders," the invaders being those forbs not found in prairies except in disturbed areas. Only perennial forbs were listed, since annuals and biennials varied greatly in numbers from season to season and year to year.

The amount of mulch in each of the four experimental pastures was ascertained by means of 50 square-foot samples. Mulch included the undecayed and partially decayed plant material that was recovered from the soil surface without removing mineral constituents 
or living plant materials. Yields of perennial grasses and forbs were obtained as well as the yield of annual grasses.

Differences in kind of vegetation in the several sites may be better understood if the available water content in each site is known. Hence soil samples were obtained to a depth of 5 feet in each site in each range-condition class.

\section{Observations and discussion}

Available water content in THE SEVERAL SITES

Available water content is shown in figure 4. Moisture content was greatest in lowland sites in all range-condition classes. It was generally least in soils of hilltops. There was considerably more available moisture in all sites of the range in excellent condition than in the other classes. The amounts of moisture in good, fair, and poor ranges were somewhat variable, but they generally were less in the poorer ranges.

An important factor, in addition to natural runoff from the upland sites and run-in water on those of the lowland, was differences in amounts of organic mulch. It will be shown that the amount of mulch in any site decreased rapidly from excellent to poor range. Another factor is the increase in density of the soil with greater degree of trampling. The decrease in organic mulch and the greater density of soil, which for brevity will not be discussed here, undoubtedly caused a decrease in rate of infiltration and an increase in runoff and thus contributed to the smaller amounts of moisture available in the poorer ranges (2).

\section{Degeneration ON LOWLAND SITES}

The lowland sites were easily distinguished from hillsides by the sharp breaks which occurred at the base of slopes and marked the beginning of banks of ravines (figs. 2, 3). The banks were rather steep and often presented catsteps. The bottoms of ravines were almost flat; sometimes terraces also oc-

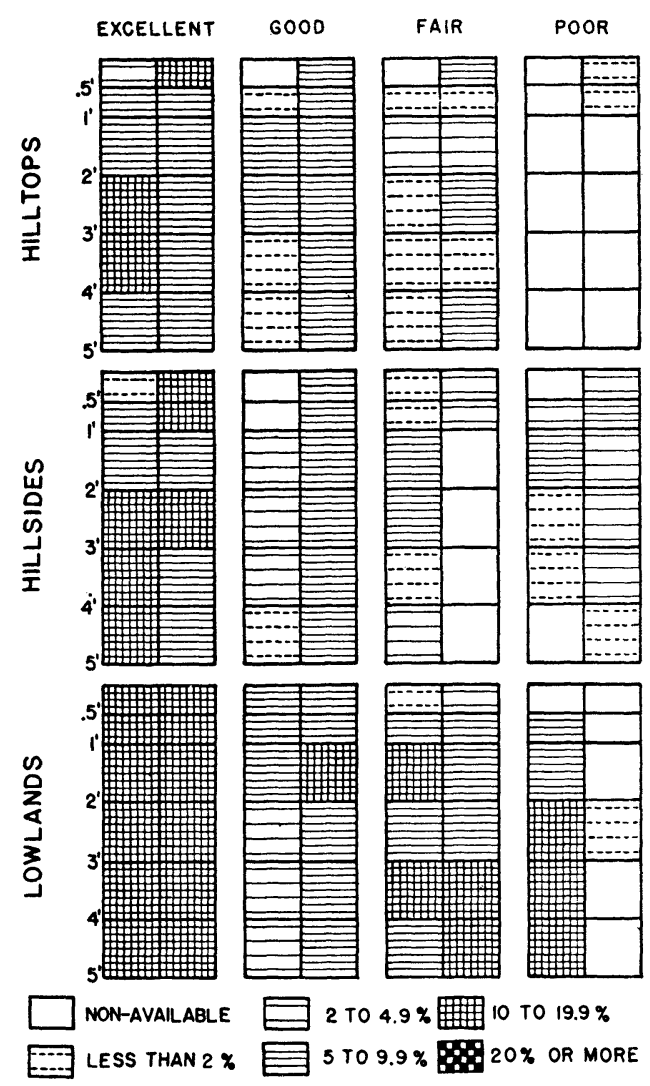

Fig. 4.-Available water content of soil on hilltop, hillside, and lowland sites in each of four rangecondition classes. Results from samples taken on June 12,1950, are shown in left half of each chart; right half shows water content on September 4, 1950.

curred. 'The soils of this site in cxcellent pastures supported a good stand of tall and mid grasses, mostly big bluestem, bluegrass (Poa pratensis), and side-oats grama (fig. 5). The story of range degeneration should properly begin here, since the lowlands were the most preferred of all grazing sites. This prefer- 
ence of livestock was due partly to the the ravines and the adjacent slopes could abundance of the most-liked of all the be grazed.

grasses-big bluestem-and to the great- CHIEF GRASSES AND BASAL AREA.er succulence of the vegetation. It was Big bluestem furnished $58 \%$ of the also due partly to the ease with which basal area in excellent lowland ranges.

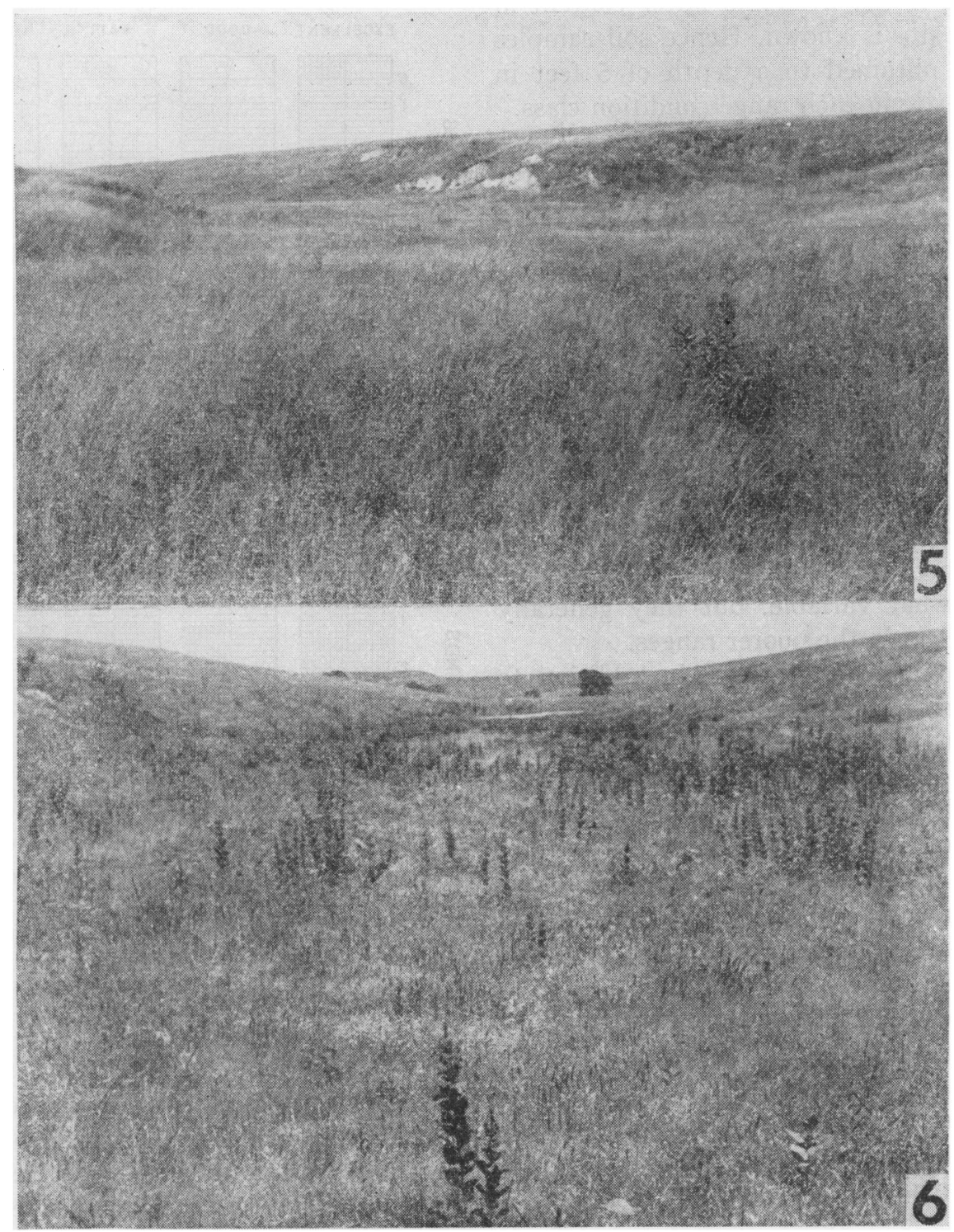

FIGs. 5, 6.-Fig. 5, excellent stand of big bluestem and side-oats grama in typical ravine. Fig. 6, view of lowland in fair range-condition class. Vegetation is buffalo grass considerably infested with little barley (Hordeum pusillum). Ironweed (Vernonia baldwinii) and hoary vervain (Verbena stricta) are chief coarse weeds. 
It and little bluestem (Andropogon scoparius), switchgrass (Panicum virgatum), nodding wild rye (Elymus canadensis), and Indian grass (Sorghastrum nutans) composed the group of decreasers (table 1). The grasses found to increase were blue grama, buffalo grass, bluegrass, and side-oats grama. Although the foliage cover varied from 80 to $100 \%$, the basal area, as is common in prairie, was only $15 \%$ (table 1).

Good pastures on lowlands were characterized by a great reduction in big bluestem. Other tall grasses, as switchgrass and nodding wild rye, found only in the most mesic portions of this site, were also less abundant. But bluegrass was nearly twice as abundant as formerly and with buffalo grass, which had increased fivefold, composed $40 \%$ of the vegetation (table 1). Big bluestem had been reduced in amount to $29 \%$, and little bluestem from 5 to $1 \%$. Other tall grasses were less abundant. Conversely, the short grasses increased, blue grama only slightly, but buffalo grass from 4 to $19 \%$. Bluegrass and side-oats grama were examples of mid grasses that increased. As a result of these changes, the basal area was doubled (31\%).

In the fair range, buffalo grass $(72 \%)$ had largely replaced the tall grasses and most of the mid grasses (fig. 6). The abundance of this sod-forming grass gave rise to the high basal area of $51 \%$.There remained only $3 \%$ of big bluestem and $3-6 \%$ of side-oats grama and bluegrass. Occasional bunches of blue grama occurred, making it the second most abundant grass $(10 \%)$. Weakened plants of big bluestem were found occasionally interspersed in the short-grass sod. Small bunches of side-oats grama were sometimes found on ravine bottoms, but it was most abundant on the drier banks of ravines. Another indicator of degen- eration was the entrance, with reduced shade, of sand dropseed. Although blue grama had an average percentage of only 10 , in the more moist eastern part of the general area almost equal amounts of blue grama and buffalo grass sometimes covered the bottoms of ravines.

In poor pastures buffalo grass constituted $44 \%$ of the perennial vegetation. Sand dropseed had increased from $2 \%$ in fair pasture to $15 \%$. It occurred in almost a third of the samples. Neither blue grama nor bluegrass had increased. There was an increase in side-oats grama. Much of the soil was devoid of perennial grasses, and the average basal area $(21 \%)$ was only two-fifths as great as that in fair pastures (table 1).

The detrimental effects of overuse were conspicuous. Buffalo grass, although more abundant than any other perennial grass, often occurred only as scattered patches. Much of the area was covered with annual weeds and unpalatable perennial forbs. Often the flat ravine bottom was drained by a gully. These central gullies were sometimes 6 feet wide and 3 feet deep and extended along the ravines throughout their length. They were a direct result of the decrease in the cover of grass.

Uniformity of distribution of species in each condition class was ascertained. In the usual sequence from excellent to poor range, big bluestem was found in $82,83,23$, and $10 \%$ of all the samples. Thus, for a long time, it maintained a wide distribution, although it decreased in amount. Blue grama occurred in 8, 18,20 , and $14 \%$. The percentage frequency of buffalo grass was in the same sequence, but this species was more widely distributed-in 5, 31, 80, and $55 \%$ of the samples. That of side-oats grama was $31,33,15$, and $8 \%$. Like the other increasers, both its percentage 
composition and its percentage frequency rose to a maximum and then, in poor ranges, decreased.

YIELD OF PERENNIAL GRASSES AND MULCH. - The lowland was the most productive of the three sites in all condition classes. The yield of excellent range was 2.44 tons of grass per acre. It far ex- ceeded that of other classes, where it became progressively less with range deterioration. The yield in fair range condition almost equaled that in good range. The fair range had a dense stand of buffalo grass that was almost as productive (1.63 tons per acre) as the mixed short and taller grasses of the same site in

TABLE 1

STAGES IN DEGENERATION OF LOWLAND VEGETATION FROM EXCELLENT THROUGH GOOD AND FAIR RANGE TO POOR RANGE CONDITION. ONLY GRASSES COMPOSING $1 \%$ OR MORE OF VEGETATION ARE LISTED IN TABLES

\begin{tabular}{|c|c|c|c|c|c|}
\hline $\begin{array}{l}\text { PERENNIAL GRASSES AND } \\
\text { PERCENTAGE COMPOSITION }\end{array}$ & DECREASERS & INCREASERS & $\begin{array}{c}\text { BASAL } \\
\text { AREA } \\
(\%)\end{array}$ & $\begin{array}{l}\text { MULCH } \\
\text { (GM/ } \\
\text { SQ FT) }\end{array}$ & $\begin{array}{c}\text { YIELD, } \\
\text { PERENNIAL } \\
\text { GRASSES } \\
\text { (TONS/ACRE) }\end{array}$ \\
\hline \multirow{3}{*}{ 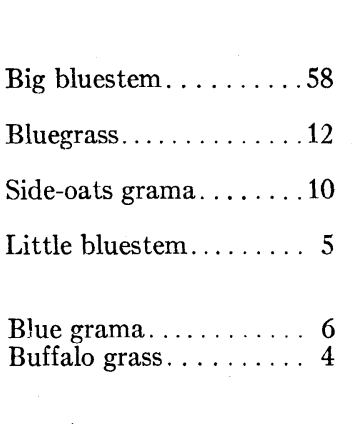 } & \multicolumn{5}{|c|}{ Excellent } \\
\hline & $\begin{array}{l}\text { Big bluestem } \\
\text { Little bluestem } \\
\text { Switchgrass } \\
\text { Nodding wild rye } \\
\text { Indian grass }\end{array}$ & $\begin{array}{l}\text { Blue grama } \\
\text { Buffalo grass } \\
\text { Bluegrass } \\
\text { Side-oats grama }\end{array}$ & 15 & 89 & 2.44 \\
\hline & \multicolumn{5}{|c|}{ Good } \\
\hline \multirow[t]{2}{*}{ 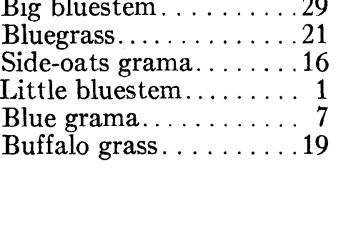 } & Same as above & Same as above & 31 & 40 & 1.67 \\
\hline & \multicolumn{5}{|c|}{ Fair } \\
\hline \multirow[t]{2}{*}{ 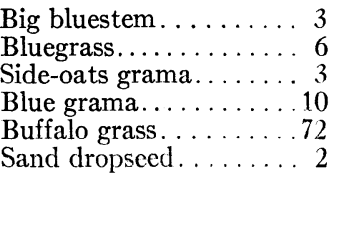 } & $\begin{array}{l}\text { Big bluestem; others } \\
\text { grazed out }\end{array}$ & Same as above & 51 & 14 & 1.63 \\
\hline & \multicolumn{5}{|c|}{ Poor } \\
\hline 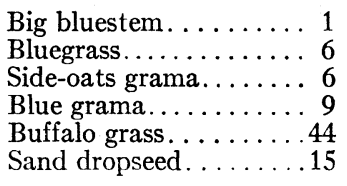 & $\begin{array}{l}\text { Traces of big blue- } \\
\text { stem }\end{array}$ & Same as above & 21 & 7 & 0.27 \\
\hline
\end{tabular}


good range. But yield in the poor range was only 0.27 ton per acre even on lowland. Decrease in mulch with decrease in yield was very marked.

The amount of mulch in pastures representing the several stages of degeneration of prairie is a feature of great importance. Decrease in amount is, aside from fire, usually a sign of overuse in grassland or a result of drought. Mulch in the lowland pastures decreased rapidly as tall and mid grasses were gradually replaced by a carpet mostly of short grass, and still further when overgrazing and trampling resulted in patches of bare soil. In excellent pastures the mulch was usually $\frac{3}{4}$ inch to more than 1 inch thick. The average air-dry weight was $89 \mathrm{gm}$. per square foot, or 8540 pounds per acre. But in good pasture the mulch was thinner, and its weight was only 3883 pounds per acre.

Because of the intensive grazing and excessive trampling in fair pasture (mostly of buffalo grass), there was a relatively small accumulation of mulch, 1300 pounds per acre. But the amount per unit area in poor pasture (634 pounds) was slightly greater than that of similar pastures on hilltop or hillside sites, chiefly because of the remnants of annual vegetation, such as sunflowers.

ChANGES IN POPULATION OF FORBS.Most abundant of the decreasers in lowland pasture were the rose (Rosa pratincola), prairie false boneset (Kuhnia glutinosa), scarlet gaura (Gaura coccinea), prairie cone-flower (Ratibida columnaris), and lead-plant (Amorpha canescens). Most of these occurred primarily on bottoms of ravines, but the rose and lead-plant grew mostly on steep banks.

Of the increasers, ironweed (Vernonia baldwinii) was the most abundant forb, and buckbrush (Symphoricarpos occidentalis) was a common shrub. Other forb increasers were many-flowered aster (Aster multiflorus), smooth goldenrod (Solidago glaberrima), western ragweed (Ambrosia psilostachya), and wavyleaved thistle (Cirsium undulatum); but these were not abundant. The only invader of any importance was hoary vervain (Verbena stricta).

In good pastures some of the decreasing forbs were grazed out, and all were considerably fewer. Conversely, practically all those listed with ironweed showed slight to considerable increase. In addition, the invading vervain became more plentiful.

lair pastures almost invariably showed further losses of decreasers. Ironweed was now the most abundant increaser, but buckbrush also had become very abundant. Western ragweed, red false mallow (Malvastrum coccineum), wavy-leaved thistle, and the invader, hoary vervain, were now also abundant.

In poor pastures perennial forbs of great abundance were ironweed and hoary vervain. Buckbrush often clothed large portions of ravines, especially the upper parts. Decreasers were nearly all grazed out.

In areas bared by grazing and trampling, a number of invading forbs, nearly all annuals, were found. Chief among these weedy plants were sunflower (Helianthus annuus), snow-on-the-mountain (Euphorbia marginata), large-bracted vervain (Verbena bracteosa), buffalo bur (Solanum rostratum), annual ragweed (Ambrosia elatior), and lamb's quarters (Chenopodium album).

\section{DEgENERATION ON HILLSIDE SITES}

Hillside sites in excellent pasture supported a mixture of short, mid, and tall grasses. The most abundant grass was blue grama. Buffalo grass was rare except for occasional narrow bands on colluvia 
soil just above the banks of ravines. Big bluestem was usually found in widely separated patches on lower slopes, but locally it was often the dominant grass (fig. 7). Little bluestem, most abundant on banks of ravines, was sometimes found as a drought relict on north-facing slopes. Over wide areas it had probably succumbed to drought $(1,10)$.

ChIEF grasses and basal area.-In excellent pastures seven grasses composed $95 \%$ of the vegetation. Table 2 shows that blue grama (64\%) and buffalo grass $(5 \%)$ were the only consistent in-

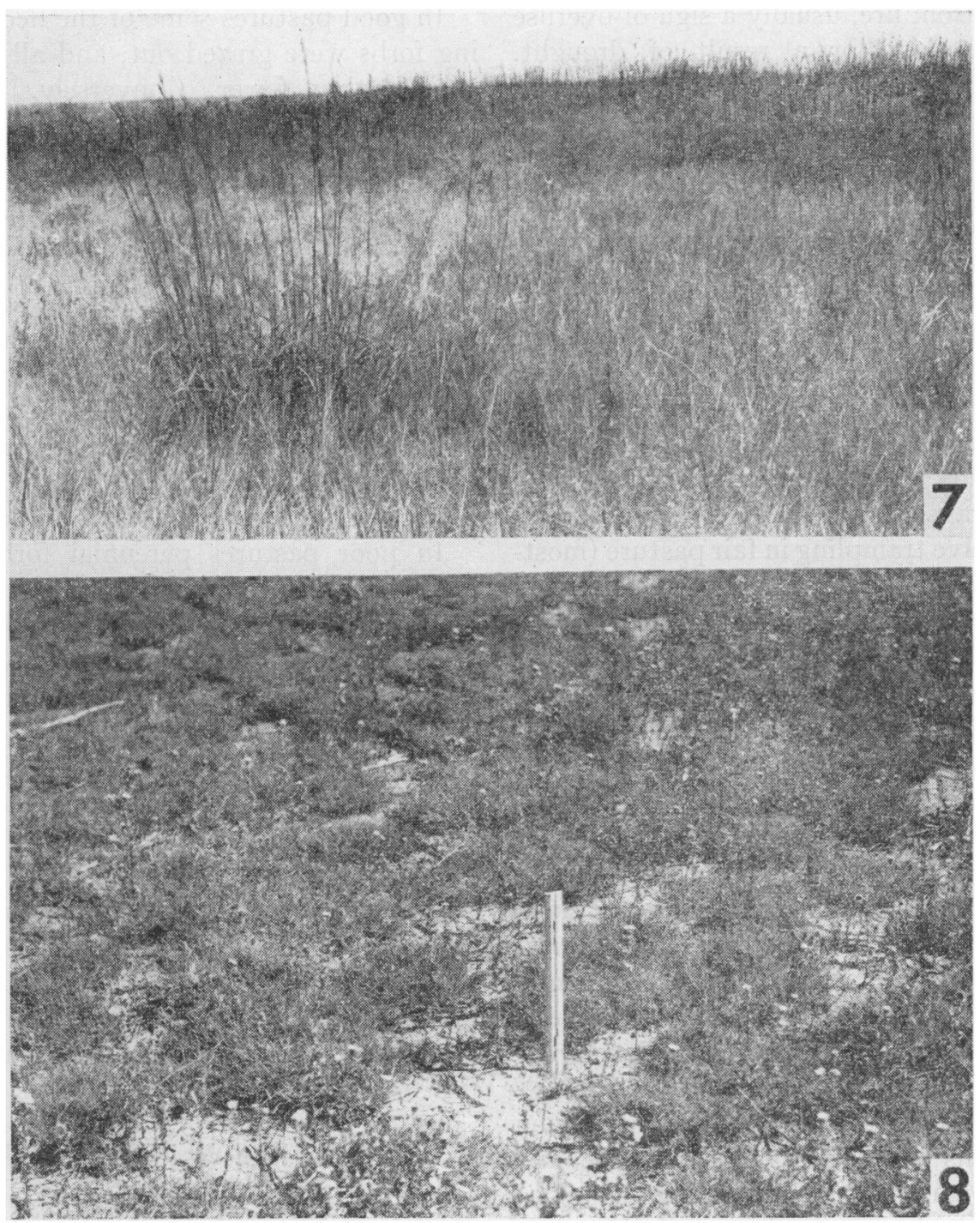

Figs. 7, 8.-Fig. 7, mixed mid, tall, and short grasses on hillside in excellent pasture near Ansley. This range had been used for grazing only in winter during two preceding years. Photographed September, 1950. Fig. 8, view showing bare areas between bunches of blue grama on hilltop of range in poor condition. Basal area has decreased from about 45 to only $11 \%$. Gumweed (Grindelia squarrosa) is chief forb. 
creasers. Side-oats grama, big bluestem, little bluestem, and bluegrass, each composing $3-10 \%$ of the perennial grasses, were all destined to decrease. This rangecondition class had an average basal area of $27 \%$.
In good pastures big bluestem was reduced from 8 to $1 \%$. Side-oats grama had only half $(5 \%)$ of its former abundance, and the percentage of other mid grasses was reduced at least two-thirds. Blue grama had increased from 64 to

TABLE 2

STAGES IN DEGENERATION OF HILLSIDE VEGETATION FROM EXCELLENT THROUGH GOOD AND FAIR TO POOR RANGE CONDITION

\begin{tabular}{|c|c|c|c|c|c|}
\hline $\begin{array}{l}\text { Perennial grasses and } \\
\text { Percentage composition }\end{array}$ & Decreasers & INCREASERS & $\begin{array}{c}\text { BASAL } \\
\operatorname{AREA}\left(\stackrel{\varphi_{0}}{0}\right)\end{array}$ & $\begin{array}{c}\text { MULCH } \\
(\mathrm{GM} / \mathrm{SQ} \text { FT })\end{array}$ & $\begin{array}{c}\text { YIELD, } \\
\text { PERENNIAL } \\
\text { GRASSES } \\
\text { (TONS/ACRE) }\end{array}$ \\
\hline \multirow{3}{*}{ 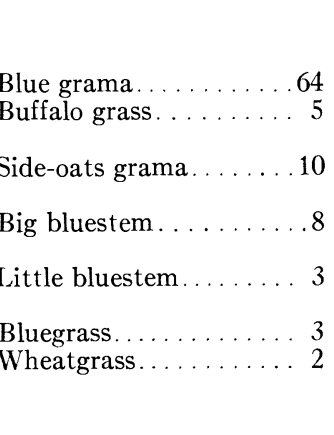 } & \multicolumn{5}{|c|}{ Excellent } \\
\hline & $\begin{array}{l}\text { Side-oats grama } \\
\text { Big bluestem } \\
\text { Little bluestem } \\
\text { Bluegrass }\end{array}$ & $\begin{array}{l}\text { Blue grama } \\
\text { Buffalo grass }\end{array}$ & 27 & 61 & 1.44 \\
\hline & \multicolumn{5}{|c|}{ Good } \\
\hline 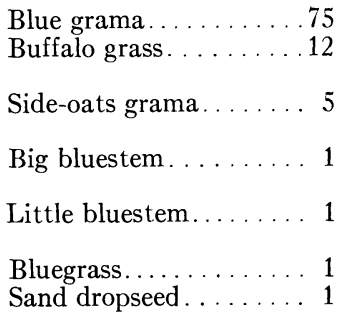 & $\begin{array}{l}\text { Side-oats grama } \\
\text { Big bluestem } \\
\text { Little bluestem } \\
\text { Bluegrass }\end{array}$ & $\begin{array}{l}\text { Blue grama } \\
\text { Buffalo grass } \\
\text { Sand dropseed }\end{array}$ & 33 & 39 & 1.33 \\
\hline \multirow{3}{*}{ 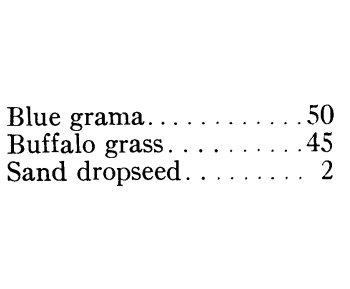 } & \multicolumn{5}{|c|}{ Fair } \\
\hline & $\begin{array}{l}\text { Mere remnants } \\
\text { of above }\end{array}$ & $\begin{array}{l}\text { Blue grama } \\
\text { Buffalo grass } \\
\text { Sand dropseed }\end{array}$ & 43 & 18 & 0.92 \\
\hline & \multicolumn{5}{|c|}{ Poor } \\
\hline 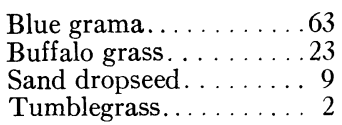 & Relicts only & $\begin{array}{l}\text { Blue grama } \\
\text { Buffalo grass } \\
\text { Sand dropseed } \\
\text { Tumblegrass }\end{array}$ & 18 & 3 & 0.41 \\
\hline
\end{tabular}


$75 \%$ and buffalo grass from 5 to $12 \%$. The increase of buffalo grass was less pronounced than on the more stable soils of lowlands, and it was accompanied by an increase in blue grama. These changes had resulted in an increase of basal cover from 27 to $33 \%$.

In fair pastures blue grama, largely owing to drought, as will be explained, had decreased a third in amount, to $50 \%$. But buffalo grass had increased from 12 to $45 \%$. Sand dropseed, side-oats grama, and red three-awn (Aristida longiseta) were found occasionally. There was a decrease in western wheatgrass. Small amounts of big bluestem and bluegrass were present on some of the eastfacing slopes. Tumblegrass (Schedonnardus paniculatus) sometimes occurred in local bared areas. As a result of the high percentage of buffalo grass, the average basal area had further increased $(43 \%)$ (table 2).

In poor hillside pastures blue grama was the most abundant grass $(63 \%)$. The bunches were often on pedestals or columns of soil 1-3 inches high, resulting from erosion around the bunches. Between the columns the soil was usually bare or populated with annual grasses and tumblegrass. Occasional patches of buffalo grass occurred on hillsides; they were most abundant on the soil of the more stable slopes. This grass composed $23 \%$ of the basal area. Thus in fair pastures the short grasses, in nearly equal abundance, composed $95 \%$ of the vegetation; but in poor ranges there was nearly three times as much blue grama as buffalo grass. Sand dropseed had increased to $9 \%$. Small amounts of western wheatgrass were present in the driest places. Other perennial grasses were rare. The cover was so open and the soil so greatly eroded that the basal area was reduced to only $18 \%$.
Percentage frequency of big bluestem on hillsides decreased with deterioration of the vegetation as follows-27, 6, 3, and 1. That of blue grama, 86, 90, 79, and 77 , remained high throughout, as did also its percentage composition. Highest percentage frequency of buffalo grass corresponded with its highest percentage composition. These were 63 and $45 \%$ in fair range but only 10 and $5 \%$ in excellent pastures. Side-oats grama occurred in $26,15,3$, and $4 \%$ of the samples, respectively, in the several pasture types.

YIELD OF PERENNIAL GRASSES AND MULCH.-Yield of grasses was much less on all hillside sites than in lowland, except in the poor pasture, where it was greater (tables 1, 2). The range was from 1.44 tons per acre in excellent pasture to only 0.41 ton in the poor one.

Mulch in the excellent pasture on hillside sites was $61 \mathrm{gm}$. per square foot or 5900 pounds per acre. The heaviest mulch was found under stands of mid and tall grasses. The decrease of these in good pasture, together with closer grazing, resulted in a reduction to 3,740 pounds. In fair pasture mulch was much less-1710 pounds per acre. Here again mulch decreased despite the greater basal area of the short-grass cover. In poor pasture, where grazing was closest and trampling was most severe, the mulch was only 281 pounds per acre.

Changes IN POPUlation OF FORBS.Decreasers composed the largest group of forbs on hillsides of excellent range. Among these, skeleton-plant (Lygodesmia juncea), prairie cone-flower, and lead-plant were most abundant. Leadplant was one of the best indicators among forbs of range condition. Although it decreased under heavy grazing, a few diminutive plants were found even in poor range. The rose also occurred on many hillside sites, but it decreased 
rapidly or disappeared with overuse of the range. Another important legume, silver-leaf psoralea (Psoralea argophylla), occurred most abundantly on hillsides. Scarlet gaura, Platte milk-vetch (Astragalus plattensis), and blazing star (Liatris punctata Hook.) were other common decreasers. The most abundant increasers were red false mallow, smooth goldenrod, many-flowered aster, and western ragweed.

In good ranges many forbs had decreased in numbers, some very greatly, and a few had disappeared. For example lead-plant, formerly with an average of five plants per 50 square feet, was now represented by less than two. The rose had lost half its numbers, and Platte milk-vetch had entirely disappeared. Of the four increasers, all but western ragweed were more abundant in good range.

In fair range, lead-plant was seldom found. Nearly all the forbs in the group of decreasers were far less abundant or even rare. The most abundant forb was western ragweed, which had more than doubled its numbers in good pasture. Of the three other chief increasers, smooth goldenrod and many-flowered aster were far more abundant than in good range.

Invaders were rare in excellent range, but a few plants of hoary vervain occurred in good pastures. Several other perennials also appeared in fair range, but hoary vervain was still of most frequent occurrence.

In poor range forb decreasers were few or none, except for prairie coneflower and skeleton-plant, which still maintained about a fourth of their original numbers, a phenomenon probably resulting from rapid reseeding in bared places.

In addition to perennial forbs, many annuals and biennials were found in pastures in poor condition. They varied considerably in abundance. In 1948 the biennial gumweed (Grindelia squarrosa) was so plentiful that the whole pasture appeared yellow when the plants were in bloom. However, during the next 2 years only scattered individuals were found. Conversely, during one summer only a few annual sunflowers were present, but during the next 2 years they were abundant and 4-6 feet high. Other abundant annuals occurring in poor pastures were horse-weed (Leptilon canadense), spotted spurge (Chamaesyce maculata), buffalo bur, and fetid marigold (Bofbera papposa).

\section{DEgENERATION ON HILLTOP SITES}

The excellent ranges on hilltops differed but little from the native prairie in their population of grasses and forbs. However, in prairie there were more mid grasses and carices (6). Changes of species during degeneration were least on these short-grass sites. Blue grama and buffalo grass composed $95 \%$ of the perennial grass cover in excellent ranges and $92 \%$ in the poor ones (table 3 ). This is in sharp contrast to changes in populations on hillsides, where mid and tall grasses finally almost disappeared. Stages in degeneration of the short-grass pastures consisted largely of the breakingdown of the more or less continuous cover of excellent ranges to an open one with interspaces between the pieces of fragmented sod (fig. 8). As the grasses lost their vigor and waned under overuse, interspaces became progressively larger, the soil was eroded, and weeds became more plentiful. Finally, in poor pastures, only isolated mats and bunches remained. These were frequently pedestaled or raised above the general eroded soil level.

CHIEF GRASSES AND BASAL AREA.- 
Causes of the great abundance of blue grama, $75 \%$ in the excellent range, were twofold. This species was harmed less than buffalo grass by severe drought, and, because it grows somewhat taller, it endured shading caused by rank growth of weeds following drought much

TABLE 3

STAGES IN DEGENERATION OF HILLTOP VEGETATION FROM EXCELLENT THROUGH GOOD AND FAIR RANGES TO POOR RANGE CONDITION

\begin{tabular}{|c|c|c|c|}
\hline $\begin{array}{c}\text { PERENNIAL GRASSES } \\
\text { AND PERCENTAGE } \\
\text { COMPOSITION }\end{array}$ & $\begin{array}{c}\text { BASAL } \\
\text { AREA } \\
(\%)\end{array}$ & $\begin{array}{l}\text { MULCH } \\
\text { (GM/ } \\
\text { SQ FT) }\end{array}$ & $\begin{array}{l}\text { YIFLD, } \\
\text { PERENNIAI } \\
\text { GRASSES } \\
\text { (TONS/ } \\
\text { ACRE) }\end{array}$ \\
\hline \multirow{3}{*}{$\begin{array}{l}\text { Blue grama.....75 } \\
\text { Buffalo grass . . . } 20 \\
\text { June grass. . . } 1\end{array}$} & \multicolumn{3}{|c|}{ Excellent } \\
\hline & 36 & 42 & 1.23 \\
\hline & \multicolumn{3}{|c|}{ Good } \\
\hline \multirow{2}{*}{$\begin{array}{l}\text { Blue grama.....65 } \\
\text { Buffalo grass ....33 }\end{array}$} & 44 & 31 & 1.32 \\
\hline & \multicolumn{3}{|c|}{ Fair } \\
\hline \multirow{2}{*}{$\begin{array}{l}\text { Blue grama ..... } 28 \\
\text { Buffalo grass.... } 68 \\
\text { Sand dropseed... } 1\end{array}$} & 49 & 11 & 0.65 \\
\hline & \multicolumn{3}{|c|}{ Poor } \\
\hline 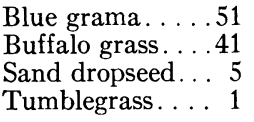 & 20 & 3 & 0.41 \\
\hline
\end{tabular}

better than did buffalo grass. Distribution of buffalo grass in the short-grass prairie was quite erratic (6).

It is probable that even most of the highly drought-resistant blue grama died in pastures heavily grazed during drought. But in pastures not grazed too heavily in subsequent years, an almost continuous cover of short grass, largely buffalo grass, which spreads rapidly by stolons, covered the soil. This is according to the findings of ALBERTSON and WEAVER (1) on changes in the vegetation of Mixed Prairie during and following the drought years. In pastures that were continuously heavily grazed, buffalo grass spread less widely and less rapidly, and the result was low basal cover with much weed-infested, open ground. In general, pastures of the latter type were in fair or poor condition.

June grass, which composed only $1 \%$ of the grasses, appeared as scattered, dark-green bunches in the short-grass cover. It is a cool-season mid grass which becomes green and attractive to livestock so early in the spring that it is grazed out.

In good pastures the decrease of blue grama to $65 \%$ was more than offset by the increase in buffalo grass to $33 \%$. This was the chief cause for the greater basal area, $44 \%$, compared with the previous $36 \%$. Sand dropseed had become slightly more abundant than in excellent range.

An outstanding feature of the cover in fair pastures was a further increase of buffalo grass to $68 \%$ and a decrease of blue grama to $28 \%$. Some of the highest hills in the extremely dissected portions of the loess plains had scattered bunches of blue grama with only small patches of buffalo grass and much exposed soil. On the more rolling topography in the eastern portion of the area, buffalo grass often formed an almost continuous sod over the hilltops. Sand dropseed was slightly more abundant in fair pastures than in good or excellent ones (table 3 ). Tumblegrass was sometimes found in local, disturbed areas. These changes resulted in a further increase in basal area to $49 \%$.

In poor range blue grama was some- 
times limited to widely separated bunches. Erosion had bared some places almost completely. The average basal cover was reduced to $20 \%$, much less than half that found in fair pastures. The soil was too unstable in many places for buffalo grass to thrive. Sand dropseed, previously of little importance, had increased to $5 \%$. Tumblegrass occurred in smaller amounts.

Big bluestem was rare on hilltop sites, with a percentage frequency of 2 . For side-oats grama it was less than 1 in all classes of hilltop pastures. Blue grama had a very high percentage frequency, 66-97. This was maintained even when the percentage composition in fair pastures was only 28 . Percentage frequency of buffalo grass varied directly with its percentage composition; these were 36 and 20 in excellent range and were 83 and 68 in fair pasture.

YIELD OF PERENNIAL GRASSES AND MULCH.-Yields of grasses ranged from 1.32 tons per acre to only 0.41 ton (table 3 ). They were less on all hilltop sites than on hillsides, except in poor pasture, where they were the same.

In excellent range the spaces between bunches of blue grama had a cover of mulch which sometimes exceeded 0.5 inch in thickness. A dry weight of $42 \mathrm{gm}$. per square foot, or 3980 pounds per acre, was found.

Ranges in good condition had an almost continuous layer of mulch. Only near fences and gates, where excessive trampling and grazing had occurred, was the soil bare. An average weight of 2980 pounds per acre was ascertained. This decrease in mulch of $25 \%$ contributed to the decrease in soil moisture on this site as compared with that in excellent range (fig. 4).

Only a moderate amount of mulch (1132 pounds per acre) was found in fair pastures on hilltops. They were usually stocked at such a rate that grazing was uniform over the entire area.

Amount of mulch on hilltops in poor ranges was extremely small, only about $3 \mathrm{gm}$. per square foot, or 281 pounds per acre. The fact that some mulch was found in all such pastures does not present an entirely true picture. It was possible to remove mulch from the bunches, even though between them the soil was not only bare but 1-3 inches of the surface had been washed or blown away.

CHANGES IN POPULATION OF FORBS.The most abundant forbs found on hilltops were prairie cone-flower and skeleton-plant. Other abundant forbs were scarlet gaura, lead-plant, silver-leaf psoralea, purple prairie-clover, blazing star, and wavy-leaved thistle. All but the last decreased with grazing. Forbs of excellent range that seldom occurred on this site in other condition classes were Platte milk-vetch and ground plum (Astragalus crassicarpus Nutt.). Leadplant was more abundant than the two preceding legumes, and, unlike them, it was found in other range classes. All the forbs, except western ragweed and wavyleaved thistle, decreased in pastures of low grade.

The chief forbs that increased with range deterioration to good pasture were Short's milk-vetch (Astragalus shortianus), red false mallow, many-flowered aster, and ironweed.

In fair pasture, forbs that decreased were rare. The three species that averaged more than one plant per $\mathbf{5 0}$ square feet were blazing star, skeleton-plant, and purple prairie-clover. The chief invader, hoary vervain, rare in excellent pastures and few in good ones, now showed a considerable increase. Some of the annual weeds mentioned in poor 
pastures of lowlands and hillsides also populated the bared soil of hilltops.

Among the relict decreasers found in poor pastures on hilltops were prairie cone-flower, scarlet gaura, and purple prairie-clover. The increaser, western ragweed, now ranked first in abundance, although all the plants in its group had become much more plentiful.

\section{TOTAL YIELD OF VEGETATION}

To complete the story of degeneration of these grasslands, the total yield of the vegetation will be given. Yield of forage was ascertained by use of exclosures

\section{TABLE 4}

TOTAL YIELD OF VEGETATION (GM/SQ M) IN EACH OF FOUR PASTURES SELECTED AS REPRESENTATIVE OF SEVERAL RANGE-CONDITION CLASSES

\begin{tabular}{c|c|c|c|c}
\hline & \multicolumn{4}{|c}{ Range-Condition class } \\
\cline { 2 - 5 } Site & Excellent & Good & Fair & Poor \\
\hline & 572 & 377 & 458 & 772 \\
Lowland... & 572 & 337 & 301 & 148 \\
Hillside.... & 352 & 319 & 163 & 127 \\
Hilltop.... & 300 & & & \\
\hline
\end{tabular}

made of steel posts and heavy woven wire. Each exclosure protected 30 square feet of range from grazing animals. A total of twenty-eight exclosures was used.

The vegetation in the exclosures was clipped only at the end of the growing season. A steel frame enclosing 2 square meters was placed in the exclosure, leaving approximately a 6-inch border of ungrazed vegetation. Vegetation in the frame was clipped to the soil surface, airdried, and weighed. Although the sampling areas were necessarily small, they were carefully selected as representative. They do give a good general indication as regards yields.

Total yields on the lowland did not differ greatly in the four ranges and were actually highest in the poor range. However, most of the yield in the poor range consisted of forb increasers and invading forbs and grasses. The most abundant invader was annual sunflower, which sometimes reached a height of 10 feet. Ironweed was by far the most abundant increaser, its woody stems extending upward 4-5 feet.

In all classes of ranges the yield on the hillside sites was greater than that from hilltops. Yield from excellent range was slightly greater than that from good or fair ranges and much greater than that from the poor one, where less than half as much vegetation was produced.

On hilltops of the excellent range total yield was slightly less than on hilltops of good range (table 4). Grasses that increased under grazing contributed greatly to this higher yield in the good class. Total yields on hilltops of the fair and poor ranges were considerably less than those in the excellent and good ones. On hilltop ranges the yield was primarily grasses. The lowest yield was found on hilltops in poor condition. Although the poor range contained many of the species that occurred in better ranges, the low height attained and the low basal area resulted in a marked decrease in productivity.

In addition to the perennial grasses and forbs, certain annual grasses, especially hairy chess (Bromus commutatus), little barley (Hordeum pusillum), and six-weeks fescue (Festuca octoflora), furnished a part of the total forage. Since they matured and dried in early summer, they were harvested at this time. Otherwise, the seeds shattered, and plants were trampled or beaten to the ground by rain.

In excellent range both distribution and abundance of annual grasses were 
similar to that in near-by prairie, except that little barley was more plentiful. Growth and yield of hairy chess were usually greatest in all sites in excellent and good pastures. Here the plants were better developed. The yield ranged between 30 and $49 \mathrm{gm}$. per square meter in all sites in excellent and good pastures, but, with one exception, from 2 to 30 $\mathrm{gm}$. in fair and poor ranges.

Little barley and six-weeks fescue, which were only 3-8 inches tall, were most abundant in fair pasture. Here there was less competition for light than in better ranges, and grazing was not so close or trampling so uniform as in poorer ranges. Yields of all annual grasses were lowest in poor range. Total average yields per square meter from excellent to poor range were $56,42,42$, and $14 \mathrm{gm}$., respectively.

\section{EXTENT OF DEGENERATION}

Ranges were examined at approximately 10-mile intervals in three directions from the center of the loess-hills area to its periphery, in order to ascertain the extent of degeneration. Each range was placed in a condition class only after comparing the composition of its vegetation with that of ranges known to be representative of each class. This included the taking of a large number of square-foot samples.

Of 148 ranges examined, only $5 \%$ were found in excellent condition. Eighteen per cent were in the good condition class. Almost half, $49 \%$, had degeneraged to the fair condition. Distinctly poor ranges composed the remaining $28 \%$ of the total.

\section{Summary}

1. An extensive area of Mixed Prairie in the loess hills of central Nebraska was studied to ascertain the degree of degen- eration that had resulted from long periods (60-70 years) of grazing.

2. The topography is mostly that of steeply rolling and hilly land. The soils, derived from loess, have A horizons varying from 6 to 20 inches in depth, carbonate accumulations in the thick $\mathrm{B}$ horizons, and C horizons of deep, mellow loess. Water from the 23.5 inches of precipitation penetrates the soil to 5 feet or more.

3. Ungrazed hilltops and upper slopes were covered mostly with short grasses. Ravines and ravine banks supported a post-climax vegetation of tall and mid grasses derived from True Prairie. Typical climax Mixed Prairie of taller grasses with an understory of short grasses occupied the long mid slopes.

4. Each type of vegetation demarked different environments or pasture sites. Various degrees of deterioration of the vegetation in each site were revealed in four range-condition classes-excellent, good, fair, and poor.

5. In lowland the chief grasses which decreased under grazing were Andropogon gerardi and other tall grasses. In excellent range $A$. gerard $i$ composed $58 \%$ of the perennial grasses, but decreased to $29 \%$, and then to $3 \%$, and finally in poor pasture to $1 \%$. Conversely, short grasses (Bouteloua gracilis and Buchloe dactyloides) increased from 10 to $82 \%$ from excellent to fair pasture, and then decreased to $53 \%$ in poor range. $P o a$ pratensis and Bouteloua curtipendula were other increasers.

6. Basal area of grasses increased with lowland range deterioration from $15 \%$ in excellent pasture to $51 \%$ in fair range, but it was only $21 \%$ in poor range. Organic mulch steadily decreased, as vegetation degenerated, from 8540 pounds per acre in excellent range to 634 pounds in poor pasture, and yield of 
perennial grasses from 2.44 tons per acre to only 0.27 ton.

7. On hillside sites Andropogon gerardi, Bouteloua curtipendula, and Poa pratensis all decreased from their respective 8,10 , and $3 \%$ composition of the vegetation to less than $1 \%$ in fair range. Bouteloua gracilis maintained a high percentage composition (50-75) throughout. Buchloe dactyloides increased from 5 to $45 \%$ in fair pasture and then decreased.

8. Basal area on hillsides increased from excellent pasture $(27 \%)$ to fair range $(43 \%)$ and then decreased to $18 \%$. In the same sequence, yields of perennial grasses were $1.44,1.33,0.92$, and 0.41 tons per acre. A yield of 5900 pounds per acre of mulch in excellent range decreased to 281 pounds in poor pasture.

9. On hilltop sites there were no tall and few mid grasses to decrease. The two short grasses composed $95 \%$ of the basal area in excellent pastures and $92 \%$ in poor ones. Here degeneration consisted largely of the fragmentation of the more or less continuous cover of excellent range to one with much bare interspace.

10. Basal area of grasses increased under grazing from 36 to $49 \%$ and then, in poor range, decreased to $20 \%$. Mulch was reduced from 3980 pounds per acre to only 281 pounds in poor range. Yields of grasses were moderate in excellent and good range (about 1.28 tons per acre) but low (0.65 and 0.41 ton) in fair and poor range.

11. The same species of forbs often grew in different sites, but some were more or less confined to a single site. Each pasture type had a characteristic group of forbs which consistently decreased with degeneration of prairie, as Amorpha canescens, Lygodesmia juncea, and Ratibida columnaris.

12. Chief forbs that increased with deterioration of grassland were Vernonia baldwinii, Aster multiflorus, Ambrosia psilostachya, and Cirsium undulatum. Among forbs that invaded degenerated grassland were Verbena stricta, Grindelia squarrosa, and, in poor pastures, Helianthus annuus and many other weedy annuals.

13. Of 148 ranges examined, only $5 \%$ were in excellent condition, $18 \%$ were in good condition, fair ranges composed $49 \%$, and distinctly poor ranges were $28 \%$ of the total.

\section{LITERATURE CITED}

1. Albertson, F. W., and Weaver, J. E. Effects of drought, dust, and intensity of grazing on cover and yield of short-grass pastures. Ecol. Monogr. 14:1-29. 1944.

2. ALDERFER, R. B., and Robinson, R. R. Runoff from pastures in relation to grazing intensity and soil compaction. Jour. Amer. Soc. Agron. 39: 948-958. 1947.

$\rightarrow$ Dyksterhuis, E. J. The vegetation of the Western Cross Timbers. Ecol. Monogr. 18:325376. 1948.

4. $-\rightarrow-$. Condition and management of range land based on quantitative ecology. Jour. Range Management 2:104-115. 1949.

5. Hayes, F. A., et al. Soil survey of Custer County, Nebraska. U.S. Dept. Agr., Bur. Chem. and Soils. 1926.

6. Hopkins, H. H. Ecology of the native vegetation of the loess hills in central Nebraska. Ecol. Monogr. 21:125-147. 1951.

7. Sampson, A. W. Succession as a factor in range management. Jour. Forestry 15:593-596. 1917.

8. United States Census of Agriculture: U.S. Department of Commerce. Vol. 1, Part 12, U.S. Bureau of the Census. 1950.

$\rightarrow$ VoIgt, J. W., and Weaver, J. E. Range condition classes of native midwestern pasture: an ecological analysis. Ecol. Monogr. 21:39-60. 1951.

$\rightarrow$ Weaver, J. E., and Bruner, W. E. Prairies and pastures of the dissected loess plains of central Nebraska. Ecol. Monogr. 18:507-549. 1948.

11. Weaver, J. E., and Hansen, W. W. Native midwestern pastures: their origin, composition, and degeneration. Univ. Nebraska Conserv. and Surv. Div. Bull. 22. 1941.

12. Weaver, J. E., and Tomanek, G. W. Ecological studies in a midwestern range: the vegetation and effects of cattle on its composition and distribution. Univ. Nebraska Conserv. and Surv. Div. Bull. 31. 1951. 